youngs). We studied the feeding effects on the number of young rabbits at birth and their performance at 70 days of age.

From the obtained information, we conclude that:

- doe-rabbits showed a racial heterogeneity which had an effect on production process;

- it is necessary to have a better bromatology knowledge of fibrous materials for a better use in rabbit feeding having regard to their low cost;

- Feed for rabbits with high energy levels (DE) gives better results; the 3 I50 kcal digestible Energy $/ \mathrm{kg}$ when adding fat are equivalent to $3000 \mathrm{kcal}$ metabolisable Energy $/ \mathrm{kg}$.

- In experimental rooms of small research units with controlled environment, we must use purebred or high level selected rabbits;

- When using fibrous materials in rabbit feeding, attention has to be paid to technological aspects, feed palatability and addition of synthesis amino-acids.

\title{
Energy and digestible protein concentration of diets Effects on growth performances of rabbits
}

\author{
Chantal DEHALIE \\ Laboratoire de Recherohes sur l'Élevage du Lapin, I.N.R.A. \\ B.P. $12-31320$ Castanet Tolosan (France)
}

Sixty 5 week-old rabbits of both sexes were offered 4 diets with a digestible energy value of $2320 \mathrm{kcal} / \mathrm{kg}$ or $2730 \mathrm{kcal} / \mathrm{kg}$ and 49.4 or $58.3 \mathrm{~g}$ digestible protein per $\mathrm{I}$ ooo $\mathrm{kcal}$ digestible energy. At the end of the 5 week experimental period the animals were slaughtered to determine the energy and protein balances. The apparent digestibility was studied during the third experimental week. Replacement of starch by straw decreased the digestible energy content of the diets. But, protein digestibility of thedifferent diets was not affected. When the digestible energy concentrations in the diets decreased, the animals kept their daily digestible energy intake fairly constant and maintained their growth rate. The digestible proteins/digestible energy ratio did not significantly affect either the apparent digestibility of the different nutrients, or the growth performances. The efficiency of protein deposition was higher when the digestible protein digestible energy ratio was low.

\section{Effects of dietary metabolisable energy concentration and physical form of the diet on the performance of growing rabbits}

\author{
D. H. MACHIN ( ${ }^{(1)}$, Catherine BUTCHER ( ${ }^{(2)}$, E. OWEN $\left({ }^{(2)}\right.$, M. BRYANT ( ${ }^{(3)}$, J. E. OWEN
}

(1) Tropical Products Institute, 56-62 Grays Inn Road, London WCIX 8 LU (United Kingdom).

(2) Reading University, Department of A griculture and Horticulture, Earley Gate, Reading RG6 $2 A T$ (United Kingdom).

This study was carried out to assess the ability of rabbits to use diets of various nutrient density and form.

In this study, 24 seven week old Californian rabbits (initial weight I.44 $\pm 0.33 \mathrm{~kg}$ ) were pair-fed 2 diets in 3 physical forms. The 2 diets $(8 \mathrm{M} / \mathrm{D}$ and I $2 \mathrm{M} / \mathrm{D}$ ) were formulated to contain 8 and $\mathrm{I} 2 \mathrm{MJ} / \mathrm{kg}$ dry matter using ruminant metabolisable energy values. Crude protein content was $160 \mathrm{~g} / \mathrm{kg}$ dry matter. Ground barley straw was the main fibre source. Diets were 
fed ad libitum until slaughter at $2 \mathrm{~kg}$ live weight, as either pellets, mash (6o p. Ioo meal, $4^{\circ} \mathrm{p}$. Ioo water) or meal in a $2 \times 3$ factorial design with 4 replicates.

Daily liveweight gain (DLG) over a 6 week period for $8 \mathrm{M} / \mathrm{D}$ mash and meal diets were 0.264 and $-6.218 \mathrm{~g} \mathrm{DLG}$ on $8 \mathrm{M} / \mathrm{D}$ pellets was $20.73 \mathrm{~g}$, and was significantly lower $(\mathrm{P}<0.0 \mathrm{I})$ than on any of the I $2 \mathrm{M} / \mathrm{D}$ treatments. DLG for diets $\mathrm{I} 2 \mathrm{M} / \mathrm{D}$ pellets, mash and meal were 33. $10,27.90$ and $26.5 \mathrm{I}$ g, respectively (SED $\leftarrow 2.32 \mathrm{I} \mathrm{g}$ ); the pelleted diet gave significantly higher DLG than meal $(\mathbf{P}<0.05)$. Mean total DM consumptions of $8 \mathrm{M} / \mathrm{D}$ pellets, $12 \mathrm{M} / \mathrm{D}$ pellets, mash and meal were $4.688, \mathrm{r} .985, \mathrm{I} .94 \mathrm{I}$ and $2.552 \mathrm{~kg}$ (SED $\pm 0.6 \mathrm{I} 4$ ), respectively. Differences were significant $(\mathrm{P}<\mathrm{o.00I})$ between $8 \mathrm{M} / \mathrm{D}$ and $\mathrm{I} 2 \mathrm{M} / \mathrm{D}$ diets.

Killing-out percentages (KO p. IOo) were $57.53,59.08,61.02$ and 63.14 or $8 \mathrm{M} / \mathrm{D}$ pellets, $\mathrm{I} 2 \mathrm{M} / \mathrm{D}$ pellets, mash and meal diets, respectively $(\mathrm{SE} D \pm 2.92)$. The $\mathrm{I} 2 \mathrm{M} / \mathrm{D}$ meal diet gave significantly $(\mathrm{P}<0.05)$ higher $\mathrm{KO} \mathrm{p}$. Ioo than the pelleted diets, while gut contents were significantly $(\mathrm{P}<\mathrm{o}$.or $)$ heavier from the $8 \mathrm{M} / \mathrm{D}$ diet.

$8 \mathrm{M} / \mathrm{D}$ mash and meal diets are clearly unsuitable for growing tabbits. The results show that both metabolisable energy concentration and form (particularly with low energy diets) are important in determining food consumption and therefore growth rate and certain carcass characteristics.

\title{
Effect of food restriction on growth performances and visceral measurements in young rabbits between 5 and 8 weeks of age
}

\author{
F. I,EBAS, J. P. I,APLACE \\ Laboratoive de Recherches sur l'Élevage du Lapin, I.N.R.A., \\ B.P. I2 - 31з2o Castanet Tolosan (France) \\ Laboratoive de Physiologie de la Nutrition, I.N.R.A. C.N.R.Z., \\ 78350 Jouy-en-Josas (France)
}

Fourty-eight Californian rabbits of both sexes, aged 5 weeks, were distributed into 4 groups corresponding to 4 techniques of administration of the same pelleted diet.

A group: ad libitum feeding every day.

$B$ group: Free access to pellets only during 5 days a week, i.e. Tuesday, Wednesday, Friday, Saturday and Sunday.

$C$ group: Daily administration of a limited quantity of pellets corresponding to $7 \mathrm{I}$ p. $100(=5 / 7)$ of the ad libitum feeding of an preexperimental group.

$D$ group: Every week, supply of the same quantity of pellets as in group C, but only two times a week on Tuesday $(3 / 7)$ and Friday $(4 / 7)$.

The animals were slaughtered at 8 weeks of age and visceral measurements were made.

Daily food intake during $2 \mathrm{I}$ days was similar for the 3 restricted groups $(B, C, D)$ and the mean, 2 I $\mathrm{p}$. I oo lower than for group A. As compared with group A, the daily live weight gain of group C was reduced by $27 \mathrm{p}$. I 00 , that of groups B and D by $48 \mathrm{p}$. Ioo. Considering the daily carcass weight gain, the reduction was similar for the 3 restricted groups (22 to 29 p. Ioo). Stomach and small bowel weight were not affected by any type of restriction. Caecum was heavier for group $\mathrm{C}$, but colon weight was reduced by $15 \mathrm{p}$. 1 oo for groups B and D. The content of viscera was enhanced for the stomach in groups $C$ and $D$ and for caecum in all restricted groups $(+4 \mathrm{I}$ to $+44 \mathrm{p}$. Ioo). The liver weight was quite the same for groups $\mathrm{A}, \mathrm{B}$ and $\mathrm{D}$, reduced by $27 \mathrm{p}$. I oo for group $\mathrm{C}$. 